International Review of Research in Open and Distributed Learning Volume 21, Number 2

April - 2020

\title{
Why do University Teachers use E-Learning Systems?
}

Chin Fei Goh, Puong Koh Hii, Owee Kowang Tan, and Amran Rasli

Azman Hashim International Business School, Universiti Teknologi Malaysia, Malaysia

\begin{abstract}
University teachers are the main players when it comes to integrating e-learning systems into higher education institutions. Prior studies have identified four main antecedents that explain teachers' technology acceptance in the educational context: (a) subjective norms (SN), (b) technological complexity (TC), (c) constructivist beliefs (CB), and (d) motivation for instrumental use (MOT). In this study, we proposed and tested the dual roles of MOT, one as a causal variable and the other as a mediating variable, to explain university teachers' acceptance of e-learning systems. To test the research model, we collected data from 174 teachers at a large public university in Malaysia using a self-administered survey. Our study shows that MOT mediates the direct effects of SN, TC, and CB on perceived ease of use (PEOU), perceived usefulness (PU), and behavioural intention (BI). This study offers important policy insight for university administrators who seek to enhance acceptance of e-learning systems among university teachers.
\end{abstract}

Keywords: e-learning, university teacher, behavioural intention, constructivist beliefs, motivation for instrumental use 


\section{Introduction}

Integrating technology into teaching and learning is a transformative process with the potential to create a meaningful educational experience to increase students' learning performance. Such technology integration represents a challenge for university administrators in enhancing the quality of an educational programme (Naaj, Nachouki, \& Ankit, 2012). Identifying what factors influence teachers' technology acceptance is important to understand how to smoothly integrate educational technologies into teaching and learning.

Prior studies have identified subjective norms (SN) and technological complexity (TC) as two important antecedents of a teachers' technology acceptance model (TAM) (Sánchez-Prieto, Olmos-Migueláñez, \& García-Peñalvo, 2016; Teo, 2009, 2010; Teo, Milutinović, \& Zhou, 2016). A recent study by Teo and Zhou (2016) showed that constructivist beliefs (CB) influence the behavioural intentions (BI) of teachers considering the adoption of educational technologies. Notably, research by Park, Lee, and Cheong (2007) extended the TAM by integrating motivation as an external factor to explain why university teachers adopt electronic courseware. Technology acceptance arises when university teachers are motivated to gratify their instrumental purposes to enhance job performance (Gautreau, 2011; J oo \& Sang, 2013; Park et al., 2007; Steel \& Hudson, 2001).

Despite the pervasive studies on teachers' technology acceptance, the focus has been on the direct effects of antecedents to TAM variables, i.e., perceived usefulness (PU), perceived ease of use (PEOU), and behavioral intention (BI) (e.g., Qin, Li, Zha, \&He, 2017; Sánchez-Prieto et al., 2016; Teo, 2009; Teo, 2010; Teo et al., 2016). Most studies have viewed these antecedents as operating independently in educational technology acceptance. Notably, individual differences in motivation among teachers have rarely been explored empirically. Such motivation, which is also known as motivation for instrumental use (MOT), is an important antecedent explaining technology acceptance (Gautreau, 2011; J oo \& Sang, 2013; Park et al., 2007). To address this knowledge gap, we draw on the idea that motivation is a complex phenomenon, in which MOT is not a standaloneantecedent in educational technology acceptance. Additionally, prior studies have shown that among university teachers, motivation to use technology can be influenced by SN, CB, and TC (Ellemers, De Gilder, \& Haslam, 2004; Friedrich, 2014; Kao, Wu, \& Tsai, 2011). Consequently, we may assume that SN, CB, and TC can explain MOT, which in turn enables MOT to predict TAM variables. Stated differently, it is important to empirically assess the dual role of MOT: as a causal variableand as a mediating variable that influences the effects of $\mathrm{SN}, \mathrm{CB}$, and TC on TAM variables. Thus, the aim of this study is to examine the effects of antecedents, i.e., SN, CB, TC, and MOT, on technology acceptance among university teachers; the dual roles of MOT are also explored.

The site of the study was a university, which reported that its teachers had low levels of motivation when it came to using e-learning systems. Such an institutional setting was suitable for investigating individual university teachers' motivations since they would have had a specific e-learning system in mind when responding to technology acceptance variables (Teo \&Zhou, 2016). 


\section{Literature Review and Development of Hypotheses}

\section{Technology Acceptance Model (TAM)}

The TAM is a major research theory that explains user acceptance of information systems (IS) through a series of causal relationships, i.e., antecedents- beliefs- attitude- behavioural intention- actual behaviour, within an organizational context (Venkatesh \& Davis, 2000). Two belief variables, namely, PU and PEOU, measure a user's subjective probability of engaging in IS adoption behaviour. PU measures a user's subjective opinion on whether an IS will improve job performance. PEOU measures the extent to which a user believes that adopting the IS will be effortless. Both belief variables have direct effects on attitudes, and theattitudes influence BI. Additionally, PU intervenes in the relationship between PEOU and attitudes, thereby making the TAM flexible for researchers to identify and manipulate the influences of antecedents on technology acceptance.

TAM studies have attempted to explain teachers' acceptance of information systems within the educational context. Consequently, the TAM for Pre-Service Teachers (TAM-PST) was developed, and it has been applied to explain user acceptance of information and communications technology mainly among preservice teachers and service teachers (Teo, 2011a, 2011b, 2012, 2014; Teo et al., 2016; Teo \& Zhou, 2016). SN and TC are the main antecedents for the TAM-PST. TC refers specifically to a teacher's perception of complexity when using an IS. Park et al. (2007) proposed and verified that motivation is another antecedent in the TAM that explains university teachers' technology acceptance in a higher-educational setting.

\section{Motivation for Instrumental Use (MOT)}

In the psychological communication literature, MOT is viewed as a major determinant of media usage (Sun, Sheng, Gu, Du, \& Min, 2017; J oo \& Sang, 2013). MOT is known as the purposive value from the utilitarian perspective; i.e., users are goal-oriented to seek benefits from media usage. Users can discern various forms of media and determine how to use media content to gratify their cognitive needs.

Motivated users tend to have a higher level of willingness to engage with their selected technology to satisfy their needs. In the higher-education context, MOT is an important driver to influence university teachers to adopt and use technology (Gautreau, 2011; Park et al., 2007; Steel \& Hudson, 2001). That is, MOT represents individual differences of university teachers, i.e., teachers are motivated by diverse goals to integrate technologies to enhance their job performance (Park et al., 2007; West, Waddoups, \& Graham, 2007).

Prior studies have verified the impact of MOT on PU and PEOU in technology acceptance (J oo \& Sang, 2013; Park, 2010; Park et al., 2007). For example, studies by Park (2010) and J oo and Sang (2013) showed that such motivation affects PU and PEOU in the usage of new telephone technology. Users with instrumental based motives are inclined to view a particular telephone technology as useful and easy to use. In the higher-education context, Park et al. (2007) also verified that university teachers' motivation to use electronic courseware is positively related to PU, PEOU, and BI. From these studies, we may conclude that university teachers with instrumental based motives tend to view a particular technology as useful and easy to use. Thus, we formulate the following hypotheses: 
H1A: Motivation for instrumental use is positively related to the perceived usefulness of an elearning system among university teachers.

H1B: Motivation for instrumental use is positively related to the perceived ease of use of an elearning system among university teachers.

H1C: Motivation for instrumental use is positively related to the behavioural intention of an elearning system among university teachers.

\section{Subjective Norms (SN)}

The SN are an important antecedent for explaining technology acceptance in workplace settings (Venkatesh \& Bala, 2008; Venkatesh \& Davis, 2000; Kim \& Nah, 2017). The SN represent individuals' perception of whether most people who are important to them think they should conform to a particular behaviour. Such influence can be divided into compliance, internalization, and identification.

First, the compliance effect arises when individuals perform a specific behaviour that is favourable in the opinions of important referents, which influences their technology acceptance (Venkatesh \& Bala, 2008). In educational technology studies, the SN are not consistent in predicting the BI (or attitude) toward technology use among pre-service teachers, teachers at the pre-university level, and university teachers (Kreijns, Vermeulen, van Buuren, \& Van Acker, 2017; Teo et al., 2016; Yuen \& Ma, 2008). In general, Venkatesh and Davis (2000) argued that the compliance effect tends to be most prominent in mandatory settings. In the context of this research, the university has mandated that university teachers use e-learning systems in all courses. Thus, we formulate the following hypothesis:

H2A: Subjective norms are positively related to the behavioural intention of an e-learning system among university teachers.

Second, the internalization effect occurs because people tend to have the same opinion on whether important referents perceive a particular system as useful (Venkatesh \& Bala, 2008). Thus, it is proposed that SN are positively related to PU in the TAM. Prior studies have verified that SN are positively related to technology use among pre-service teachers and teachers in instructional settings (Teo, 2010, 2012; Teo, Lee, \& Chai, 2008; Yuen \& Ma, 2008). Thus, we formulate the following hypothesis:

H2B: Subjective norms are positively related to the perceived usefulness of an e-learning system among university teachers.

Finally, an identification effect occurs when individuals intend to derive social recognition from their important referents. This phenomenon is manifested through the indirect effect between SN and PU (Venkatesh \& Bala, 2008). It is described as how "individuals perceive their motivation and perspective to be psychologically interchangeable with those of others who share the same social identity" (Haslam, Powell, \& Turner, 2000). For example, if most university administrators and influential academics share the same social identity concerning the use of e-learning systems, such social identification will induce university teachers to adhere to group norms (Ellemers et al., 2004) and perhaps express corresponding 
levels of motivation to use e-learning systems. This direct effect is the precondition for exerting an indirect effect on PU. Thus, we formulate the following hypothesis:

H2C: Subjectivenorms are positively related to motivation for theinstrumental use of an e-learning system among university teachers.

\section{Constructivist Beliefs (CB)}

Preference represents the teaching beliefs of teachers (Aypay, 2011; Chan \&Elliott, 2004). Such beliefs will affect teaching orientations, whether teaching or learning centred (Samuelowicz \& Bain, 2001). Teachingcentred orientation is geared towards imparting information and transmitting structured knowledge to learners, whereas learning-centred orientation focuses on supporting students.

Constructivist learning is an important teaching and learning belief, and it involves instructional scaffolding for promoting a deeper level of understanding (Sang, Valcke, van Braak, \& Tondeur, 2010). It is a studentcentred approach, which encourages students to explore knowledge, express ideas, conduct group discussions, and construct their own understandings individually and independently.

The impact of teachers' CB on technology acceptance has been widely explored in the current literature (e.g., J udson, 2006; Overbay, Patterson, Vasu, \&Grable, 2010; Teo, Chai, Hung, \& Lee, 2008; Teo \&Zhou, 2016; Tondeur, Hermans, van Braak, \& Valcke, 2008; Wang, Quek, \& Hu, 2017). These studies largely suggest that teachers' CB are associated with the extensive use of technologies to support student-centred curricula. Teachers can implement constructivist pedagogies by using technologies to engage students in cognitive learning activities and thus advance constructive learning. Recent studies have shown that teachers with high CB tend to integrate technology into their teaching (Overbay et al., 2010; Teo, Chai, et al., 2008; Teo \& Zhou, 2016). It is possible that teachers with high CB are more likely to use e-learning because they are more willing to explore the pedagogical use of new technologies (Chai, 2010; Kim, Kim, Lee, Spector, \&DeMeester, 2013). Thus, we formulate the following hypothesis:

H3A: Constructivist beliefs are positively related to the behavioural intention of an elearning system among university teachers.

Beliefs represent determinants of motivation for individuals who can rationalize their motives instrumentally (Friedrich, 2014). This argument is supported by the study of Kao et al. (2011), which confirmed that teachers' beliefs predict their motives for web-based professional development; i.e., the teachers are aware of the potential benefits of using an IS through the cognitive instrumental process. For teachers with high $\mathrm{CB}$, the technology use must be compatible with student learning.

E-learning systems are effective tools for supporting a constructivist learning environment, as most elearning systems are specially designed to support a learner-centred environment and promote autonomy (Kuo, Belland, Schroder, \& Walker, 2014). Accordingly, elearning offers flexibility and convenience in terms of location and schedule. E-learning allows students to pace themselves and collaborate. In other words, the instrumental benefit of using e-learning is the major role it plays in $\mathrm{BI}$, particularly when teachers with $\mathrm{CB}$ view e-learning as consistent with their teaching beliefs (Keengwe, Onchwari, \&Agamba, 
2014; Nawaz \& Kundi, 2011). Teachers will continue to be motivated to use digital teaching vehicles that can support their pedagogical approach (Wright, 2015). Thus, we formulate the following hypothesis:

H3B: Constructivist beliefs are positively related to motivation for instrumental use of an e-learning system among university teachers.

\section{Technological Complexity (TC)}

TC refers to a users' perceived degree of difficulty in understanding and using an IS (Teo et al., 2016). A higher level of TC adversely influences a user's willingness to adopt an IS. TC is closely related to the userperceived amount of effort that is required to complete a task. In an instructional setting, several studies have verified that TC influences pre-service teachers' PEOUs and intentions to use a particular technology (Teo, 2009, 2010; Teo et al., 2016). Thus, we expect the perceived TC among university teachers should adversely influence the PEOU and BI of an e-learning system, and we formulate these hypotheses:

H4A: Technological complexity is negatively related to the perceived ease of use of an e-learning system among university teachers.

H4B: Technological complexity is negatively related to the behavioural intention of an e-learning system among university teachers.

The perception of high difficulty of using a particular system may adversely affect motivation to adopt that system (Kao et al., 2011). If users perceive a system as difficult and confusing, they may not be able to evaluate the potential instrumental benefits. This argument is supported in a study by Kao et al. (2011), which showed that perceived difficulty is negatively related to web-based professional development among teachers. Thus, we formulate the following hypothesis:

H4C: Technological complexity is negatively related to motivation for instrumental use of an elearning system among university teachers.

Based on the above hypotheses, a research model is proposed (see Figure 1). 


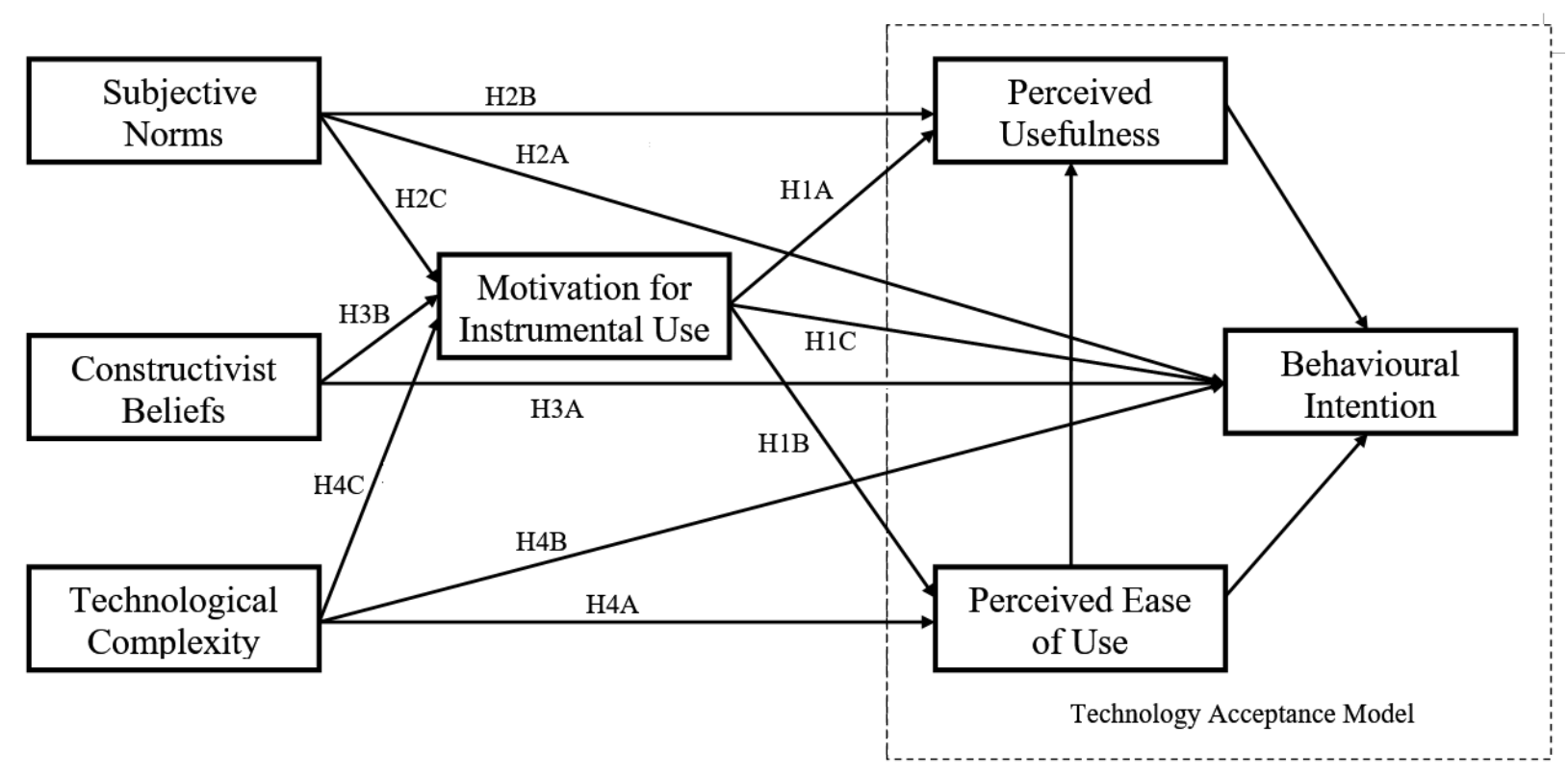

Figure 1. E-Learning Systems Research Model.

\section{Research Questions}

This study is designed to answer the following questions about the use of e-learning systems among university teachers:

1. Do subjective norms have a direct influence on motivation for instrumental use, perceived usefulness, and behavioural intention?

2. Do constructivist beliefs have a direct influence on motivation for instrumental use and behavioural intention?

3. Does technological complexity have a direct influence on motivation for instrumental use, perceived ease of use, and behavioural intention?

4. Does motivation for instrumental use have a direct influence on perceived usefulness, perceived ease of use, and behavioural intention?

\section{Method}

\section{Measures}

Instruments used in this research have been adapted from prior studies in the educational and technology acceptance literature. The BI scale was adapted from previous e-learning acceptance studies (see Gibson, Harris, \& Colaric, 2008; Ma, Andersson, \& Streith, 2005). The measures for MOT, PEOU, and PU were 
adapted from a related study by Park et al. (2007), which investigated university teachers' acceptance of electronic courseware. SN and TC scales were adapted from educational technology studies (see Teo, 2010; van Schaik \& Teo, 2013). Finally, the CB scale was adapted from the work of Sang et al. (2010). All items in the seven constructs were anchored on a 5-point Likert scale, which ranged from 1 (strongly disagree) to 5 (strongly agree). All survey instruments were reviewed by two experts to determine their validity and clarity within the higher education context in Malaysia. The first expert was a professor of information systems and the second was an academician of e-learning and information systems. The survey instruments were modified slightly based on their feedback.

\section{Participants}

This study was a campus-wide investigation of university teachers' intentions to use an e-learning system. The selected higher institution was a large public university in Malaysia that has adopted the Moodle course management system. A self-administered questionnaire was developed, and questionnaires were distributed to lecturers door-to-door at the university. Informed consent was obtained from respondents before commencing data collection. In total, researchers received 178 completed questionnaires. Among them, 4 questionnaires were excluded because the amount of missing data exceeded 15\%, leaving 174 available for analysis. Slightly over half (51.7\%) of the respondents were male, while $48.3 \%$ were female. The majority of the respondents (48.8\%) were between 31 and 40 years of age. Most respondents had more than 15 years of teaching experience (39.7\%) and possessed PhDs (83.9\%).

\section{Data Analysis and Results}

\section{Common-Method Variance}

Harman's single-factor test was performed to identify the common-method variance, which is mainly due to self-report bias. Self-report bias may occur if respondents who answer perceptual measures of independent and dependent variables at the same time give consistent responses to questions that are otherwise unrelated. Our analysis shows that the largest variance that can be explained by individual factors is $29.5 \%$. A single factor neither emerges nor accounts for the majority of the variances among measures; thus, common-method variance can be ruled out.

\section{Assessment of the Measurement Model}

In PLS-SEM, the assessment of a measurement model seeks to verify construct reliability (i.e., indicator reliability and internal consistency) and validity (i.e., convergent validity and discriminant validity). The discriminant validity was assessed using the Heterotrait-Monotrait (HTMT) ratio (Henseler, Ringle, \& Sarstedt, 2015). The HTMT ratio criterion uses a multitrait-multimethod matrix to establish discriminant validity. The HTMT ratio criterion is based on a relative measurement between the average correlations of indicators across latent variables that measure different phenomena and the average correlation of indicators within the same latent variable.

Our analysis shows that all psychometric properties are validated in this study (see Table 1). First, all composite reliability (CR) values are greater than 0.70 , and all average variance extracted (AVE) values are 
above 0.50 , which are greater than threshold levels, thereby confirming the internal consistency and convergent validity for all constructs. All indicator loadings meet or exceed the 0.70 threshold, except for item CB7. However, item CB7 is retained because the internal consistency and the convergent validity of its construct are established (Hair, Hult, Ringle, \& Sarstedt, 2013). Because all HTMT values are lower than the maximum threshold of 0.85 , the discriminant validity is established (see Table 2).

Table 1

Results of Measurement Models

\begin{tabular}{|c|c|c|}
\hline Construct & Items & $\begin{array}{l}\text { Indicator } \\
\text { loadings }\end{array}$ \\
\hline \multirow{3}{*}{$\begin{array}{l}\mathrm{BI} \\
\mathrm{CR}=0.93 ; \mathrm{AVE} \\
=0.81\end{array}$} & I plan to use the e-learning system continuously in the future. & 0.88 \\
\hline & $\begin{array}{l}\text { Whenever possible, I intend to use e-learning in my future } \\
\text { teaching. }\end{array}$ & 0.87 \\
\hline & $\begin{array}{l}\text { To the extent possible, I intend to use the e-learning system to } \\
\text { perform different teaching tasks. }\end{array}$ & 0.94 \\
\hline \multirow{7}{*}{$\begin{array}{l}\mathrm{PU} \\
\mathrm{CR}=0.90 ; \mathrm{AVE} \\
=0.55\end{array}$} & I am teaching in new ways since using the e-learning system. & 0.72 \\
\hline & $\begin{array}{l}\text { Students' performance is enhanced when using the e-learning } \\
\text { system. }\end{array}$ & 0.78 \\
\hline & I interact more with students when using the e-learning system. & 0.80 \\
\hline & $\begin{array}{l}\text { Some students participate on the e-learning system who do not } \\
\text { participate in class discussions. }\end{array}$ & 0.70 \\
\hline & Students like to use the e-learning system. & 0.77 \\
\hline & I save time by using the e-learning system. & 0.71 \\
\hline & The e-learning system is a central component of my courses. & 0.73 \\
\hline \multirow{3}{*}{$\begin{array}{l}\text { PEOU } \\
\text { CR =0.89; AVE } \\
=0.73\end{array}$} & The e-learning system is easy for me to use. & 0.86 \\
\hline & The e-learning system is easy for students to use. & 0.92 \\
\hline & The e-learning system is convenient for students to access. & 0.78 \\
\hline \multirow{2}{*}{$\begin{array}{l}\mathrm{SN} \\
\mathrm{CR}=0.95 ; \mathrm{AVE} \\
=0.85\end{array}$} & $\begin{array}{l}\text { People whose opinions I value will encourage me to use the e- } \\
\text { learning system. }\end{array}$ & 0.90 \\
\hline & $\begin{array}{l}\text { People who are important to me will support me in using the e- } \\
\text { learning system. }\end{array}$ & 0.94 \\
\hline
\end{tabular}


People who are important to me think it is a good idea to use the

e-learning system.

\begin{tabular}{|c|c|c|}
\hline \multirow{6}{*}{$\begin{array}{l}\text { MOT } \\
\mathrm{CR}=0.90 ; \mathrm{AVE} \\
=0.60\end{array}$} & Keep up with technical change. & 0.76 \\
\hline & Increase communication among students. & 0.75 \\
\hline & Save time. & 0.81 \\
\hline & Respond to student requests or interest. & 0.79 \\
\hline & Learn more about the e-learning system. & 0.76 \\
\hline & Help students learn to use the e-learning system. & 0.79 \\
\hline \multirow{4}{*}{$\begin{array}{l}\text { TC } \\
\text { CR =0.93; AVE } \\
=0.78\end{array}$} & $\begin{array}{l}\text { Learning to use the e-learning system takes up too much of my } \\
\text { time. }\end{array}$ & 0.89 \\
\hline & $\begin{array}{l}\text { Using the e-learning system is so complicated that it is difficult to } \\
\text { know what is going on. }\end{array}$ & 0.89 \\
\hline & Using the e-learning system involves too much time. & 0.87 \\
\hline & It takes too long to learn how to use the e-learning system. & 0.88 \\
\hline \multirow{7}{*}{$\begin{array}{l}\mathrm{CB} \\
\mathrm{CR}=0.88 ; \mathrm{AVE} \\
=0.51\end{array}$} & I make it a priority in my classroom to give students time to work & 0.68 \\
\hline & $\begin{array}{l}\text { I involve students in evaluating their own work and setting their } \\
\text { own goals. }\end{array}$ & 0.71 \\
\hline & $\begin{array}{l}\text { I believe that expanding on students' ideas is the effective way to } \\
\text { build my curriculum. }\end{array}$ & 0.78 \\
\hline & $\begin{array}{l}\text { I prefer to cluster students' desks or use tables, so they can work } \\
\text { together. }\end{array}$ & 0.75 \\
\hline & $\begin{array}{l}\text { I prefer to assess students informally through observations and } \\
\text { conferences. }\end{array}$ & 0.75 \\
\hline & $\begin{array}{l}\text { I often create thematic units based on the students' interests and } \\
\text { ideas. }\end{array}$ & 0.71 \\
\hline & I invite students to create many of my bulletin boards. & 0.58 \\
\hline
\end{tabular}

Note. $\mathrm{CR}$ = composite reliability; $\mathrm{AVE}$ = average variance extracted; $\mathrm{BI}=$ behavioural intention; $\mathrm{PU}$ = perceived usefulness; $\mathrm{PEOU}=$ perceived ease of use; $\mathrm{SN}$ = subjective norms; $\mathrm{MOT}=$ motivation for instrumental use; $\mathrm{TC}=$ technological complexity; $\mathrm{CB}=$ constructivist beliefs. 
Table 2

Heterotrait- Monotrait Criterion

\begin{tabular}{lccccccc}
\hline & BI & CB & MOT & PEOU & PU & SN & TC \\
\hline BI & - & & & & & & \\
CB & 0.40 & - & & & & & \\
MOT & 0.68 & 0.49 & - & & & \\
PEOU & 0.59 & 0.18 & 0.48 & - & & \\
PU & 0.66 & 0.39 & 0.72 & 0.55 & - & \\
SN & 0.36 & 0.16 & 0.33 & 0.24 & 0.34 & - & \\
TC & 0.37 & 0.12 & 0.29 & 0.52 & 0.28 & 0.06 & - \\
\hline
\end{tabular}

Note. $\mathrm{BI}=$ behavioural intention; $\mathrm{CB}=$ constructivist beliefs; $\mathrm{MOT}=$ motivation for instrumental use; $\mathrm{PEOU}=$ perceived ease of use; $\mathrm{PU}=$ perceived usefulness; $\mathrm{SN}=$ subjective norms; $\mathrm{TC}=$ technological complexity.

\section{Assessment of the Structural Model and Mediation Analyses}

We used bootstrapping with 5,000 resamples to estimate the structural model (see Table 3). In PLS-SEM, the structural model presents information about path analysis, explained variance $\left(\mathrm{R}^{2}\right)$, predictive relevance $\left(\mathrm{Q}^{2}\right)$, and standardized root mean square residual (SRMR). This study shows that BI is predicted by SN, MOT, PU, and PEOU, which results in an $\mathrm{R}^{2}$ value of 0.51 . The $\mathrm{R}^{2}$ values for PEOU, PU, and MOT are 0.31, 0.46 , and 0.30 , respectively. The predictive relevance of all endogenous constructs is verified because all $\mathrm{Q}^{2}$ values are greater than zero. The SRMR values for the saturated and estimated models are 0.075 and 0.077 respectively, which are less than the 0.08 threshold level, thereby suggesting an acceptable model fit (Henseler, Hubona, \& Ray, 2016). Finally, all VIF values are less than 3.3, which indicates the absence of multicollinearity. 
Table 3

Assessment of Structural Model

\begin{tabular}{|c|c|c|c|}
\hline Endogenous constructs & R-square & Q-square & \\
\hline $\mathrm{BI}$ & 0.51 & 0.36 & \\
\hline MOT & 0.30 & 0.15 & \\
\hline PU & 0.46 & 0.22 & \\
\hline PEOU & 0.31 & 0.19 & \\
\hline Model Fit Criterion & Saturated Model & Estimated Model & \\
\hline SRMR & 0.075 & 0.077 & \\
\hline Relation & $\begin{array}{l}\text { Path coefficient ( } t- \\
\text { value) }\end{array}$ & $\begin{array}{l}\text { 95\% Biased corrected } \\
\text { confidence interval }\end{array}$ & Conclusion \\
\hline $\mathrm{PU} \rightarrow \mathrm{BI}$ & $0.21(2.76)^{* * *}$ & $(0.06,0.36)$ & - \\
\hline $\mathrm{PEOU} \rightarrow \mathrm{BI}$ & $0.22(2.73)^{* * *}$ & $(0.06,0.38)$ & - \\
\hline $\mathrm{PEOU} \rightarrow \mathrm{PU}$ & $0.24(3.15)^{* * *}$ & $(0.08,0.38)$ & - \\
\hline $\mathrm{MOT} \rightarrow \mathrm{PU}(\mathrm{H} 1 \mathrm{~A})$ & $0.50(7.90)^{* * * *}$ & $(0.37,0.61)$ & Supported \\
\hline MOT $\rightarrow$ PEOU (H1B) & $0.32(3.77)^{* * *}$ & $(0.13,0.47)$ & Supported \\
\hline MOT $\rightarrow$ BI (H1C) & $0.26(3.34)^{* * *}$ & $(0.11,0.41)$ & Supported \\
\hline $\mathrm{SN} \rightarrow \mathrm{BI}(\mathrm{H} 2 \mathrm{~A})$ & $0.12(2.08)^{* *}$ & $(0.01,0.24)$ & Supported \\
\hline $\mathrm{SN} \rightarrow \mathrm{PU}(\mathrm{H} 2 \mathrm{~B})$ & $0.12(1.732)^{\text {n.s. }}$ & $(-0.01,0.25)$ & Not Supported \\
\hline $\mathrm{SN} \rightarrow \mathrm{MOT}(\mathrm{H} 2 \mathrm{C})$ & $0.24(2.70)^{* * *}$ & $(0.08,0.44)$ & Supported \\
\hline $\mathrm{CB} \rightarrow \mathrm{BI}(\mathrm{H} 3 \mathrm{~A})$ & $0.12(1.81)^{\text {n.s. }}$ & $(-0.02,0.25)$ & Not Supported \\
\hline $\mathrm{CB} \rightarrow \mathrm{MOT}(\mathrm{H} 3 \mathrm{~B})$ & $0.38(5.63)^{* * *}$ & $(0.23,0.50)$ & Supported \\
\hline $\mathrm{TC} \rightarrow \mathrm{PEOU}(\mathrm{H} 4 \mathrm{~A})$ & $-0.37(5.47)^{* * *}$ & $(-0.50,-0.23)$ & Supported \\
\hline $\mathrm{TC} \rightarrow \mathrm{BI}(\mathrm{H} 4 \mathrm{~B})$ & $-0.10(1.43)^{\text {n.s. }}$ & $(-0.23,0.04)$ & Not Supported \\
\hline $\mathrm{TC} \rightarrow \mathrm{MOT}(\mathrm{H} 4 \mathrm{C})$ & $-0.24(3.07)^{* * *}$ & $(-0.39,-0.09)$ & Supported \\
\hline
\end{tabular}

Note. $\mathrm{BI}=$ behavioural intention; $\mathrm{MOT}=$ motivation for instrumental use; PU = perceived usefulness; $\mathrm{PEOU}=$ perceived ease of use; $\mathrm{SN}=$ subjective norms; $\mathrm{CB}=$ constructivist beliefs; $\mathrm{TC}=$ technological complexity. ${ }^{* * *} \mathrm{p}<0.01$; ${ }^{* *} \mathrm{p}<0.05$; n.s non-significant

The results show that hypotheses H1A, H1B, and H1C are supported, indicating MOT positively influences PU, PEOU, and BI, suggesting that university teachers who are aware of their motives tend to view elearning systems as worthwhile and easy to use.

Support for hypothesis H2A is confirmed, i.e., SN exert a positive impact on BI. This result suggests that university teachers comply with social influence to use e-learning systems in their teaching practices. Nevertheless, the hypothesis H2B is not supported in this study, i.e., SN are not related to PU. Finally, the analysis shows that $\mathrm{H} 2 \mathrm{C}$ is supported, implying that $\mathrm{SN}$ positively influence MOT.

The study shows that hypothesis H3A is not supported, i.e., university teachers' CB are not related to BI. The finding suggests that for university teachers, CB do not have a direct relationship with integrating 
technology into their teaching. However, the analysis shows that hypothesis H3B is supported, indicating university teachers with CB have a higher level of MOT.

The findings support hypothesis H4A, i.e., TC is negatively related to PEOU. However, TC is not related to $\mathrm{BI}$, and thus hypothesis H4B is not supported. Finally, support for H4C confirms that TC is negatively related to MOT.

To examine the mediation effects, a series of indirect effect analyses were performed. Full mediation occurs when the indirect effects are significant, but the direct effect is not significant (Nitzl, Roldán, \& Cepeda Carrión, 2016). Partial mediation exists when both the direct and indirect effects are significant. The results reveal that MOT mediates the following relationships: CB-BI, SN-BI, TC-BI, TC-PEOU, and SN-PU (see Table 4). The analysis of direct and indirect effects shows that full mediation occurs for relations CB-BI, TC-BI, and SN-PU, whereas partial mediation occurs for relations SN-BI and TC-PEOU.

Table 4

Mediating Analysis

\begin{tabular}{lcccl}
\hline Mediation & $\begin{array}{c}\text { Direct } \\
\text { effect }\end{array}$ & $\begin{array}{c}\text { Indirect } \\
\text { effect }\end{array}$ & $\begin{array}{c}\text { 95\% Confidence } \\
\text { intervals bias corrected } \\
\text { (indirect effect) }\end{array}$ & \multicolumn{1}{c}{ Interpretation } \\
\hline $\mathrm{CB} \rightarrow \mathrm{MOT} \rightarrow \mathrm{BI}$ & $0.12^{\text {n.s. }}$ & $0.10^{* * *}$ & $(0.04,0.17)$ & Full mediation \\
$\mathrm{SN} \rightarrow \mathrm{MOT} \rightarrow \mathrm{BI}$ & $0.12^{* *}$ & $0.06^{* *}$ & $(0.02,0.15)$ & Partial mediation \\
$\mathrm{TC} \rightarrow \mathrm{MOT} \rightarrow \mathrm{BI}$ & $-0.10^{\text {n.s. }}$ & $-0.06^{* *}$ & $(-0.14,-0.02)$ & Full mediation \\
$\mathrm{TC} \rightarrow \mathrm{MOT} \rightarrow \mathrm{PEOU}$ & $-0.37^{* * *}$ & $-0.08^{* *}$ & $(-0.16,-0.02)$ & Partial mediation \\
$\mathrm{SN} \rightarrow \mathrm{MOT} \rightarrow \mathrm{PU}$ & $0.12^{\text {n.s. }}$ & $0.12^{* *}$ & $(0.04,0.24)$ & Full mediation \\
\hline
\end{tabular}

Note. $\mathrm{BI}=$ behavioural intention; PU = perceived usefulness; PEOU = perceived ease of use; MOT = motivation for instrumental use; $\mathrm{SN}=$ subjective norms; $\mathrm{CB}=$ constructivist beliefs; $\mathrm{TC}=$ technological complexity. ${ }^{* * *} \mathrm{p}<0.01$; ${ }^{* *} \mathrm{p}<0.05$; ${ }^{\text {n.s }}$ non-significant

\section{Validation of Survey Results With University Administrators}

We supplemented the survey analysis with face-to-face interviews with five university administrators who are department heads at this university. They were asked to rate their agreement from 1 (strongly disagree) to 5 (strongly agree) on six questions concerning the survey results. The first three questions asked the respondents' views on whether SN, TC, and MOT are important antecedents that explain university teachers' acceptance of e-learning systems. The next three questions asked the respondents' opinion on whether MOT would mediate the effects of SN, TC, and CB in university teachers' acceptance of an elearning system. The means for the six questions were 4.0, 4.0, 4.6, 4.0, 4.0, and 4.2, respectively. The results imply all respondents consistently validated the survey results. 


\section{Discussion}

As in many studies, the survey responses show that university teachers' SN, CB, and TC are significantly related to MOT, and the latter is related to TAM variables PU, PEOU, and BI. Surprisingly, only one of three antecedents, which is university teachers' SN, is significantly related to BI. The non-significant effects of university teachers' $\mathrm{CB}$ and TC on BI are not in accordance with prior TAM studies in educational contexts (Teo, 2011a, 2011b, 2012, 2014; Teo et al., 2016; Teo \& Zhou, 2016). We identify one plausible reason for these non-significant relations: MOT may assume dual functions, namely, as a causal and a mediating variable in technology acceptance. The mediation analysis indicates that MOT fully mediates the relations CB-BI, TC-BI, and SN-PU, and partially mediates relations SN-BI and SN-PU. The mediating effects indicate that MOT cannot be separated when investigating the influences of SN, CB, and TC on university teachers' technology acceptance. The reason is that MOT plays an intermediate role (as a process factor) in the relationships between antecedents and technology acceptance. University teachers have higher levels of willingness and awareness of the instrumental benefits of accomplishing a task with technology.

\section{Theoretical Contributions of this Study}

This study makes several contributions to the educational technology acceptanceliterature. First, this study advances our understanding of the nature of SN, CB, and TC in influencing university teachers to use an elearning system. We integrated MOT into an educational TAM based on an interdisciplinary literature review (e.g., Friedrich, 2014; Kao et al., 2011), from which new insights into the interrelationships among external factors (SN, CB, and TC) for MOT in the TAM were obtained. The supported hypotheses that were developed in this study augment the technology acceptance literature. Second, our study analysed causal mediating effects to offer a more thorough understanding of what drives BI among university teachers. Mediation analysis indicates that MOT absorbs all or some direct effects from SN, CB, and TC on TAM variables. The presence of mediators also clarifies the non-significant relations CB-BI, TC-BI, and SN-PU among university teachers.

\section{Implications for Application}

Creating a technology-friendly environment may be inadequate for motivating university teachers to integrate technology into teaching (Lladós-Masllorens, Aibar, Meseguer-Artola, Minguillón, \&Lerga, 2017; Teo \&Zhou, 2016). University administrators should understand why university teachers believe the use of a particular technology can contribute to their pedagogical objectives. This study offers several suggestions for improving technology use among university teachers.

First, this study suggests that university administrators should focus on developing university teachers' epistemological beliefs and their perceptions of potential instrumental benefits of using technology in teaching. University administrators may consider providing regular training and promotional campaigns to advance university teachers' epistemological beliefs, particularly their CB. Such actions may promote constructivist learning environments (Kennedy, 2016; Marra, 2005). Further training and orientation will enhance university teachers' MOT for using e-learning systems. Second, this study suggests that university administrators should instil a strong organizational culture that encourages the use of e-learning systems. If individuals view using e-learning in teaching as a form of social compliance with the organizational culture, this awareness may lead to greater group conformity and uptake of e-learning systems. 
Furthermore, influential academicians in the university (or faculty) can be requested to lead the change by adopting an e-learning system. A university teacher's perception and motivation to use an e-learning system may be enhanced if the influential academicians actively demonstrate their belief in such systems.

\section{Limitations of the Study and Future Research}

There are several limitations in this study. First, this study has investigated the effect of MOT on behavioural intention to integrate technology into teaching. However, future studies may consider integrating the affective (or emotional) components of motivational factors to better understand intentions to use. Another limitation arises from the fact the survey was distributed door-to-door by one of the researchers. Only those university teachers present in their offices were requested to respond to the survey. Thus, our results may not apply to the wider target population. The third limitation is that conceptions of good teaching are affected by discipline and teaching context. Future research could focus on whether discipline differences affect the willingness of university teachers to integrate technology into their teaching. Lastly, our results may not apply to private universities because only public universities are required by the Malaysian Ministry of Higher Education to adopt e-learning in teaching activities.

\section{Conclusions}

Sustainable use of educational technology is of paramount importance for higher-education institutions due to the expensive investment required. To gauge university teachers' willingness to use such technology, a thorough examination of external factors is important for clarifying the relationships among PU, PEOU, and BI. Previous TAM studies were reviewed to develop a more comprehensive explanation of university teachers' acceptance of information systems. In this study, we advanced current understanding by identifying the dual roles of MOT, as both cause and mediator. Our results highlight that policy intervention

must cover all antecedents (SN, CB, and TC) and MOT to enhance technology acceptance among university teachers. 


\section{References}

Aypay, A. (2011). The adaptation of the teaching-learning conceptions questionnaire and its relationships with epistemological beliefs. Educational Sciences: Theory and Practice, 11(1), 21-29.

Chai, C.S. (2010). The relationships among Singaporean preservice teachers' ICT competencies, pedagogical beliefs and their beliefs on the espoused use of ICT. The Asia-Pacific Education Researcher, 19(3), 387-400. Retrieved from http:// hdl.handle.net/ 10497/4791

Chan, K.-W., \& Elliott, R.G. (2004). Relational analysis of personal epistemology and conceptions about teaching and learning. Teaching and Teacher Education, 20(8), 817-831. doi: 10.1016/j.tate.2004.09.002

Ellemers, N., De Gilder, D., \& Haslam, S.A. (2004). Motivating individuals and groups at work: A social identity perspective on leadership and group performance. Academy of Management Review, 29(3), 459-478. doi: 10.5465/amr.2004.13670967

Friedrich, D. (2014). Belief and motivation. Theoria, 80(3), 255-268. doi: 10.1111/theo.12030

Gautreau, C. (2011). Motivational factors affecting the integration of a learning management system by faculty. J ournal of Educators Online, 8(1), 1-25. Retrieved from https:// eric.ed.gov/ ?id=EJ 917870

Gibson, S.G., Harris, M.L., \& Colaric, S.M. (2008). Technology acceptance in an academic context: Faculty Acceptance of online education. J ournal of Education for Business, 83(6), 355-359. doi: 10.3200/J OEB.83.6.355-359

Hair, J .F., Hult, G.T.M., Ringle, C.M., \& Sarstedt, M. (2013). A primer on partial least squares structural equation modeling (PLS-SEM). Thousand Oaks: Sage.

Haslam, S.A., Powell, C., \& Turner, J . (2000). Social identity, self-categorization, and work motivation: Rethinking the contribution of the group to positive and sustainable organisational outcomes. Applied Psychology, 49(3), 319-339. doi: 10.1111/1464-0597.00018

Henseler, J ., Hubona, G., \& Ray, P.A. (2016). Using PLS path modeling in new technology research: Updated guidelines. Industrial Management \&Data Systems, 116(1), 2-20. doi: 10.1108/IMDS$\underline{09-2015-0382}$

Henseler, J ., Ringle, C.M., \& Sarstedt, M. (2015). A new criterion for assessing discriminant validity in variance-based structural equation modeling. J ournal of the Academy of Marketing Science, 43(1), 115-135. doi: 10.1007/s11747-014-0403-8

J oo, J ., \& Sang, Y. (2013). Exploring Koreans' smartphone usage: An integrated model of the technology acceptance model and uses and gratifications theory. Computers in Human Behavior, 29(6), 2512-2518. doi: 10.1016/j.chb.2013.06.002 
Judson, E. (2006). How teachers integrate technology and their beliefs about learning: Is there a connection? J ournal of Technology and Teacher Education, 14(3), 581-597. Retrieved from https:// www.learntechlib.org/ primary/ p/6046/

Kao, C.-P., Wu, Y.-T., \& Tsai, C.-C. (2011). Elementary school teachers' motivation toward web-based professional development, and the relationship with Internet self-efficacy and belief about webbased learning. Teaching and Teacher Education, 27(2), 406-415. doi: 10.1016/j.tate.2010.09.010

Keengwe, J ., Onchwari, G., \&Agamba, J . (2014). Promoting effective e-learning practices through the constructivist pedagogy. Education and Information Technologies, 19(4), 887-898. doi: 10.1007/s10639-013-9260-1

Kennedy, M.M. (2016). How does professional development improve teaching? Review of Educational Research, 86(4), 945-980. doi: 10.3102/0034654315626800

Kim, C., Kim, M.K., Lee, C., Spector, J .M., \& DeMeester, K. (2013). Teacher beliefs and technology integration. Teaching and Teacher Education, 29, 76-85. doi: 10.1016/j.tate.2012.08.005

Kim, Y., \&Nah, S. (2017). Internet researchers' data sharing behaviors: An integration of data reuse experience, attitudinal beliefs, social norms, and resource factors. Online Information Review, 42(1), 124-142. doi: 10.1108/OIR-10-2016-0313

Kreijns, K., Vermeulen, M., van Buuren, H., \&Van Acker, F. (2017). Does Successful Use of Digital Learning Materials Predict Teachers' Intention to Use Them Again in the Future? The International Review of Research in Open and Distributed Learning, 18(7), 158-174. doi: 10.19173/irrodl.v18i7.2895

Kuo, Y.-C., Belland, B.R., Schroder, K.E.E., \&Walker, A.E. (2014). K-12 teachers' perceptions of and their satisfaction with interaction type in blended learning environments. Distance Education, 35(3), 360-381. doi: $10.1080 / 01587919.2015 .955265$

Lladós-Masllorens, J ., Aibar, E., Meseguer-Artola, A., Minguillón, J . \& Lerga, M. (2017). Explaining teaching uses of Wikipedia through faculty personal and contextual features. Online Information Review, 41(5), 728-743. doi: 10.1108/OIR-10-2016-0298

Ma, W.W.-k., Andersson, R., \& Streith, K.-O. (2005). Examining user acceptance of computer technology: an empirical study of student teachers. J ournal of Computer Assisted Learning, 21(6), 387-395. doi: 10.1111/j.1365-2729.2005.00145.x

Marra, R. (2005). Teacher beliefs: The impact of the design of constructivist learning environments on instructor epistemologies. Learning Environments Research, 8(2), 135-155. doi: 10.1007/s10984005-7249-4 
Naaj, M.A., Nachouki, M., \&Ankit, A. (2012). Evaluating student satisfaction with blended learning in a gender-segregated environment. J ournal of Information Technology Education: Research, 11(1), 185-200. Retrieved from https:// www.learntechlib.org/p/111500/

Nawaz, A., \& Kundi, G.M. (2011). Users of e-learning in higher education institutions (HEIs): perceptions, styles and attitudes. International J ournal of Teaching and Case Studies, 3(2-4), 161-174. doi: 10.1504/ijtcs.2011.039555

Nitzl, C., Roldán, J.L., \& Cepeda Carrión, G. (2016). Mediation Analysis in Partial Least Squares Path Modeling: Helping Researchers Discuss More Sophisticated Models. Industrial Management \& Data Systems, 116(9), 1849-1864. doi: 10.1108/IMDS-07-2015-0302

Overbay, A., Patterson, A.S., Vasu, E.S., \&Grable, L.L. (2010). Constructivism and technology use: findings from the IMPACTing Leadership project. Educational Media International, 47(2), 103120. doi: $\underline{10.1080 / 09523987.2010 .492675}$

Park, N. (2010). Adoption and Use of Computer-Based Voice Over Internet Protocol Phone Service: Toward an Integrated Model. J ournal of Communication, 60(1), 40-72. doi: 10.1111/j.14602466.2009.01440.x

Park, N., Lee, K.M., \& Cheong, P.H. (2007). University instructors' acceptance of electronic courseware: An application of the technology acceptance model. J ournal of Computer-Mediated Communication, 13(1), 163-186. doi: 10.1111/j.1083-6101.2007.00391.x

Qin, L., Li, N., Zha, S., \& He, W. (2017). Research on factors influencing perceived usefulness of a virtual teacher community: A case study of rural teachers in Inner Mongolia, China. Telematics and Informatics, 34(5), 463-471. doi: 10.1016/j.tele.2016.09.008

Samuelowicz, K., \& Bain, J .D. (2001). Revisiting academics' beliefs about teaching and learning. Higher Education, 41(3), 299-325. doi: 10.1023/A:1004130031247

Sánchez-Prieto, J .C., Olmos-Migueláñez, S., \& García-Peñalvo, F.J . (2016). Informal tools in formal contexts: Development of a model to assess the acceptance of mobile technologies among teachers. Computers in Human Behavior, 55, Part A, 519-528. doi: 10.1016/j.chb.2015.07.002

Sang, G., Valcke, M., van Braak, J ., \& Tondeur, J . (2010). Student teachers' thinking processes and ICT integration: Predictors of prospective teaching behaviors with educational technology. Computers \&Education, 54(1), 103-112. Retrieved from http:// hdl.handle.net/ 1854/ LU-850547

Steel, J ., \& Hudson, A. (2001). Educational Technology in Learning and Teaching: The Perceptions and Experiences of Teaching Staff. Innovations in Education and Teaching International, 38(2), 103111. doi: $10.1080 / 13558000010030158$

Sun, J ., Sheng, D., Gu, D., Du, J . \& Min, C. (2017). Understandinglink sharing tools continuance behavior in social media. Online Information Review, 41(1), 119-133. doi: 10.1108/OIR-08-2015-0261 
Teo, T. (2009). Modelling technology acceptance in education: A study of pre-service teachers. Computers \&Education, 52(2), 302-312. doi: 10.1016/j.compedu.2008.08.006

Teo, T. (2010). A path analysis of pre-service teachers' attitudes to computer use: applying and extending the technology acceptance model in an educational context. Interactive Learning Environments, 18(1), 65-79. doi: 10.1080/10494820802231327

Teo, T. (2011a). Factors influencing teachers' intention to use technology: Model development and test. Computers \&Education, 57(4), 2432-2440. doi: 10.1016/j.compedu.2011.06.008

Teo, T. (2011b). Technology acceptance research in education. AW Rotterdam: Sense Publisher.

Teo, T. (2012). Examining the intention to use technology among pre-service teachers: an integration of the technology acceptance model and theory of planned behavior. Interactive Learning Environments, 20(1), 3-18. doi: 10.1080/10494821003714632

Teo, T. (2014). Unpacking teachers' acceptance of technology: Tests of measurement invariance and latent mean differences. Computers \& Education, 75, 127-135. doi: 10.1016/j.compedu.2014.01.014

Teo, T., Chai, C.S., Hung, D., \& Lee, C.B. (2008). Beliefs about teaching and uses of technology among pre-service teachers. Asia-Pacific J ournal of Teacher Education, 36(2), 163-174. doi: 10.1080/13598660801971641

Teo, T., Lee, C.B., \& Chai, C.S. (2008). Understanding pre-service teachers' computer attitudes: applying and extending the technology acceptance model. J ournal of Computer Assisted Learning, 24(2), 128-143. doi: 10.1111/j.1365-2729.2007.00247.x

Teo, T., Milutinović, V., \& Zhou, M. (2016). Modelling Serbian pre-service teachers' attitudes towards computer use: A SEM and MIMIC approach. Computers \& Education, 94, 77-88. doi: 10.1016/j.compedu.2015.10.022

Teo, T., \&Zhou, M. (2016). The influence of teachers' conceptions of teaching and learning on their technology acceptance. Interactive Learning Environments, 1-15. doi: 10.1080/10494820.2016.1143844

Tondeur, J ., Hermans, R., van Braak, J ., \&Valcke, M. (2008). Exploring the link between teachers' educational belief profiles and different types of computer use in the classroom. Computers in Human Behavior, 24(6), 2541-2553. doi: 10.1016/j.chb.2008.02.020

van Schaik, P., \&Teo, T. (2013). Understanding technology acceptance in pre-service teachers: a structural-equation modeling approach. The Asia-Pacific Education Researcher, 18(1), 47-66.

Venkatesh, V., \& Bala, H. (2008). Technology Acceptance Model 3 and a Research Agenda on Interventions. Decision Sciences, 39(2), 273-315. doi: 10.1111/j.1540-5915.2008.00192.x 
Venkatesh, V., \& Davis, F.D. (2000). A Theoretical Extension of the Technology Acceptance Model: Four Longitudinal Field Studies. Management Science, 46(2), 186-204. doi: 10.1287/mnsc.46.2.186.11926

Wang, Q., Quek, C.L., \& Hu, X. (2017). Designing and Improving a Blended Synchronous Learning Environment: An Educational Design Research. The International Review of Research in Open and Distributed Learning, 18(3), 99-118. doi: 10.19173/irrodl.v18i3.3034

West, R.E., Waddoups, G., \& Graham, C.R. (2007). Understanding the experiences of instructors as they adopt a course management system. Educational Technology Research and Development, 55(1), 1-26. doi: 10.1007/ s11423-006-9018-1

Wright, N. (2015). A case for adapting and applying continuance theory to education: understanding the role of student feedback in motivating teachers to persist with including digital technologies in learning. Teachers and Teaching, 21(4), 459-471. doi: 10.1080/13540602.2014.969105

Yuen, A.H., \&Ma, W.W. (2008). Exploring teacher acceptance of e-learning technology. Asia-Pacific J ournal of Teacher Education, 36(3), 229-243. doi: 10.1080/13598660802232779

\section{Athabasca University}

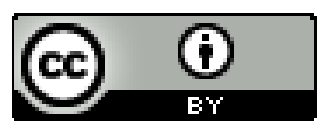

